\title{
Description of Students' Scientific Literacy Competencies on the Scientific Issue of Flat Earth Theory
}

\author{
Agus Widayoko \\ Physics Education, Postgraduate Program, State University of Malang, Indonesia, \\ widayokoagus22@gmail.com
}

\section{Praptika Septi Femilia}

Faculty of Teacher Training and Education, State Institute of Islamic Studies Jember, Indonesia, praptikaseptifemilia@gmail.com

\author{
Albertus Djoko Lesmono \\ Faculty of Teacher Training and Education, State University of Jember, Indonesia, \\ albertdlesmono@gmail.com
}

Heri Sudjatmi

State Senior High School of 8 Malang, Indonesia, sudjatmi@gmail.com

Vicki Dian Prastiwi

State Senior High School of 7 Malang, Indonesia, dian_cki13@yahoo.com

Ninik Munfarikha

Islamic Senior High School of Pujon Malang, Indonesia, ninikrikha@gmail.com

\begin{abstract}
Scientific literacy is one of the basic competencies that must be possessed in the XXI century. These competencies include explaining scientific phenomena, designing and evaluating scientific investigations, and interpreting scientific data and facts. These three competency indicators must be embedded in students to help them to solve problems and give the best responding to issues especially science issues, as well as "flat earth theory". The purpose of this study was to describe students' scientific literacy competencies in responding to scientific issues "flat earth theory" and their indications in responding to issues. This research is a description research by questionnaire method and interview. The research subjects were 92 students in several high schools in Malang. The questionnaire results show that $95.65 \%$ of students rejected the "flat earth theory". Among those who rejected the theory, $20.97 \%$ of respondents did not conduct an investigation to conclude the information of the theory. The interview results of this research indicate that students only relied on initial knowledge or initial information to conclude the issue.
\end{abstract}

Keywords: science literacy, physics issues, the flat earth theory, competence, students

\section{INTRODUCTION}

The flat earth theory is not a new discussion on scientific science. The concept of flat earth had been constructed by the Babylonians since 2500 BC (Prahasta, 2001). According to the Babylonians, this earth is a kind of floating disk on an ocean or slab. The adherents of the theory move massively till nowadays. On the modern era, the Flat Earth Theory movement was developed in England by Samuel Birley Rowbotham in 1850. Zateticism posited that the earth is not round but a wide plain, uneven and

Citation: Widayoko, A., Femilia, P. S., Lesmono, A. D., Sudjatmi, H., Prastiwi, V. D., \& Munfarikha, N. (2019). Description of Students' Scientific Literacy Competencies on the Scientific Issue of Flat Earth Theory. Anatolian Journal of Education, 4(2), 31-38. https://doi.org/10.29333/aje.2019.424a 
unmovable (Brough, 1872). The old basic concept of the flat earth theory believed that the earth was such spinning record, where the North Pole was in the middle of the record and the edge of the record was the south one with its high ice wall and no one had crossed it (Weinberg, 1986). Recently, the concept of the flat earth theory has virally entered Indonesia through several justification videos about the flat earth.

During the beginning of modern technology development in the $21^{\text {st }}$ century, science education and technology has become a developed benchmark of a country. The fast development specifically occurs on technology and globalization (Liu, 2009). Science education primarily should be able to be applied to filter current technology development. Science education as a part of general education is responsible and has an important role to create and form critical, logic, creative, innovative, and globally competitive students (Abidin et al., 2017). Science takes an important role in developing the character of the society and nation because of the fast progress of knowledge, the process efficacy to transfer to other fields, and the availability of value and attitude within (Rustaman, 2007). In addition, there is also a correlation among the students' character, science interest and scientific literacy (Bybee \& McCrae, 2011; Abidin et al., 2017). Science education has to able to form the individual character which is completed with a good immunity towards the technology development. Scientific literacy is one topic within science education considered being able to face the technology development, such as responding hoaxes on science and technology.

Technological developments in Indonesia cannot be prevented. The development of technology provides easy access to information. This results in information that can be easily obtained by the community as well as students, whether correct or wrong information or hoaxes. Without good knowledge and critical information, people will easily believe in any information, including scientific information. Scientific literacy competence is a skill needed by Indonesian society.

The scientific literacy has become the competence benchmark of senior high school graduates. Science education at school should be able to stimulate the scientific literacy competencies. Scientific literacy presents the human being's thinking capacity, the basis of language development, the logic and problem solving, the basis of any issues or information comprehension, useful to the lifetime and to determine the progress of a nation (National Research Council (NRC), 2007; Abidin et al., 2017). Thus, the senior high school graduates have to and are able to apply the scientific literacy competencies (American Association for Advancement of Science (AAAS), 1993; National Research Council (NRC), 1996b).

The purpose of this study was to describe students' scientific literacy competencies in responding to scientific issues "flat earth theory" and their indications in responding to issues. This research describes student's answers and their analogies with scientific literacy competencies. This research can be used as information on the level of scientific literacy of Indonesian students.

\section{METHOD}

\section{Research Design}

Descriptive study was used as the research design. It was conducted in October 2017 in Malang. The subject of the study was 100 senior high students as the respondents who were the $10^{\text {th }}$ graders up to the $12^{\text {th }}$ graders. Of the 100 respondents, 8 respondents were invalid because they did not fill out the questionnaire according to the procedure. So, just 92 respondents were valid and it's used to subjects of research. All the respondents were assumed to have already had background knowledge about the theory of earth since they were junior high students. Table 1 shows the description of the research subjects. 
Table 1

Identity of Research Subjects

\begin{tabular}{lllll}
\hline School Name & SMAN 8 & SMAN 7 & SMA Islam Pujon & Total \\
\hline Number of respondents & 36 & 24 & 32 & 92 \\
\hline \multirow{3}{*}{ Grade } & $10^{\text {th }}$ grades = 20 Students & & $10^{\text {th }}$ grades $=8$ Students & 28 \\
\cline { 2 - 5 } & & $11^{\text {th }}$ grades $=24$ & $11^{\text {th }}$ grades $=12$ & 36 \\
& & Students & Students & \\
\cline { 2 - 5 } & & & $12^{\text {th }}$ grades $=12$ Students & 28 \\
\hline \multirow{2}{*}{ Gender } & Boy & 38 & & \\
\cline { 2 - 5 } & Girl & 54 & & \\
\hline
\end{tabular}

\section{Research Procedure}

The procedure implemented in this study was: 1) creating questionnaire; 2) trying out questionnaire; 3 ) finding out respondents; 4) collecting data; 5) processing data; and 6) drawing conclusion.

Data was collected through close-ended questionnaire and interview. The questionnaire was given to 92 respondents. The close-ended questionnaire was used to obtain the students' responses dealing with the study. The interview was given to students to explore their answer.

\section{a) Close-ended Questionnaire}

The study applied closed-ended questionnaire. Two questions of closed-ended questionnaire were distributed to the respondents through the questionnaire. The first question was aimed to get the students' responses about the flat earth theory. The students' responses were led to accept or reject the truth of the flat earth theory. Meanwhile, on the second question, the students were asked about their action taken to respond the flat earth theory. For this question, the students were allowed to choose more than one answer. The first choice was indicated as the first scientific literacy competence, which explained the phenomenon scientifically. The second choice was indicated as the competence of designing and evaluating scientific investigation. The third choice was indicated as the competence of interpreting data and facts scientifically. The fourth choice was used as the indicator that the students did not apply literacy competence in responding such issue. PISA 2015 stated that a science literate student mastered those 3 competences. In this study only described each competence possessed by the students.

\section{The first question}

It is viral on cyberspace nowadays, especially on social media, about the flat earth theory. This theory states that the earth is actually flat and a kind of slab, not paced round on its both poles as what people believe today's, in responding the flat earth theory, I:

a. Accept the truth of the flat earth theory

b. Reject the truth of the flat earth theory

\section{The second question}

Put a tick $(\sqrt{ })$ on the square on what you have done to respond the flat earth theory. Note: (square $=$ option)

To respond the flat earth theory, I:

a. use my background theory, information and facts (knowledge) as the explanation of the theory (square 1)

b. investigate, review literature and find out reliable trusted sources as the explanation of the theory (square 2)

c. criticize the data and facts of current investigations as the explanation of the theory (square 3 )

d. do nothing to obtain the explanation of the theory (square 4)

The description of student responses to the second question can be seen in table 2 .

Anatolian Journal of Education, October $2019 \bullet$ Vol.4, No.2 
Table 2

Description of the Analysis of Scientific Literacy Competency in the Second Question

\begin{tabular}{ll}
\hline \multicolumn{1}{c}{ Responses } & \multicolumn{1}{c}{ Indicators } \\
\hline $\begin{array}{l}\text { I use my background theory, information and facts } \\
\text { (knowledge) as the explanation of the theory }\end{array}$ & $\begin{array}{l}\text { Students who have this response are able to remember and use } \\
\text { theories, ideas, information and facts in responding to news or } \\
\text { information properly }\end{array}$ \\
\hline $\begin{array}{l}\text { I investigate, literature reviewing and finding out } \\
\text { reliable trusted sources as the explanation of the } \\
\text { theory }\end{array}$ & $\begin{array}{l}\text { Students who have this response are able to design, conduct, } \\
\text { and evaluate the process of investigations or scientific } \\
\text { experiments }\end{array}$ \\
\hline $\begin{array}{l}\text { I criticize the data and facts of current investigations } \\
\text { as the explanation of the theory }\end{array}$ & $\begin{array}{l}\text { Students who have this response are able to look for patterns, } \\
\text { present data, perform statistical tests, argue, and criticize }\end{array}$ \\
\hline I do nothing to obtain the explanation of the theory & Students do not do anything \\
\hline
\end{tabular}

b) Interview

The purpose of using the interview was to find out more about students' responses to "flat earth theory". By using the interview, it is expected to provide students flexibility in giving opinions regarding "flat earth theory". The interview sample was four students consisting of two boys and two girls. The purpose of choosing an interview sample is to find out the response of boy and girl students related to the issue. The sample selection is done by selecting one boy and girl student from the group of students with the same answer (general) and one boy and girl student who has a unique (special) answer. So, it can represent the whole sample. In this questionnaire, there were four questions that were submitted (Table 3). Four questions asked in the open-ended were as follow:

a. Do you know the flat earth theory?

b. Do you accept the flat earth theory?

c. What do you do to investigate the flat earth theory?

d. What is on your minds related to the flat earth theory?

Table 3

Interview Questionnaire Description

\begin{tabular}{ll}
\hline $\begin{array}{l}\text { Questions } \\
\text { Do you know the flat earth } \\
\text { theory? }\end{array}$ & $\begin{array}{l}\text { Purposes } \\
\text { The expected answer is "Yes" or "No". flat earth theory is a new thing in Indonesia, } \\
\text { especially among students, so few students know this science issue. }\end{array}$ \\
\hline $\begin{array}{l}\text { Do you agree the flat earth } \\
\text { theory? }\end{array}$ & \begin{tabular}{l} 
The expected answer is "agree" or "disagree". \\
\hline $\begin{array}{l}\text { What do you do to } \\
\text { investigate the flat earth } \\
\text { theory? }\end{array}$
\end{tabular} $\begin{array}{l}\text { The expected answer is that students write in full what is done by students to ensure that } \\
\text { the student is "agree" or "disagree". The results of the description of the answers will be } \\
\text { grouped based on similarity descriptions. The results of the grouping will be an analysis } \\
\text { of scientific literacy competencies (Table 4). }\end{array}$ \\
$\begin{array}{l}\text { What is on your minds } \\
\text { related to the flat earth } \\
\text { theory? }\end{array}$ & $\begin{array}{l}\text { The purpose of this question is to find out the quick response of students when they hear } \\
\text { "flat earth theory". This quick response is used as a statement of emphasis regarding the } \\
\text { issue of "Flat Earth Theory" science. }\end{array}$ \\
\hline
\end{tabular}

From the results of the interviews, the data obtained will be grouped according to the indicators of scientific literacy competencies (Table 4). 
Table 4

Grouping of Students Capability based on Scientific Literacy Competencies

\begin{tabular}{ll}
\hline Scientific Literacy Competencies & Capability coverage \\
\hline Explaining phenomenon & Remember and apply appropriate scientific knowledge \\
scientifically & $\begin{array}{l}\text { Identify, produce, and use clear models and representations } \\
\text { Make and justify jurisdiction appropriately } \\
\text { Propose a hypothesis } \\
\text { Explain the potential implications of scientific knowledge for society }\end{array}$ \\
\hline Designing and evaluating & Identify questions as a result of exploration of scientific research provided \\
scientific investigations & $\begin{array}{l}\text { Distinguish questions that can be investigated scientifically } \\
\text { Propose ways to explore questions that are given scientifically }\end{array}$ \\
& $\begin{array}{l}\text { Evaluate how to explore questions that are given scientifically } \\
\text { Explain and evaluate how scientists ensure data reliability, objectivity, and } \\
\text { generalized explanations }\end{array}$ \\
\hline Interpreting data and facts & $\begin{array}{l}\text { Change data from one type of presentation to another type of presentation } \\
\text { Analyze, interpret, and draw the right conclusions }\end{array}$ \\
& $\begin{array}{l}\text { Identify assumptions, evidence, and reasoning in science texts } \\
\text { Distinguish arguments based on scientific evidence and theory with those based on } \\
\text { other considerations }\end{array}$ \\
& $\begin{array}{l}\text { Evaluate arguments and scientific evidence from different sources (such as } \\
\text { newspapers, internet, and journals) }\end{array}$ \\
\hline
\end{tabular}

\section{Data Analysis}

The obtained data were analysed using descriptive statistics for close-ended questionnaire and data reduction for interview questionnaire data. The procedures applied in analysing data are: 1) examining data; 2) counting the frequency of data and reducing the same of data; 3) counting the percentage; 4) visualizing data; and 5) interpreting data. The result of data analysis was used to describe the students' responses and the students' scientific literacy competence towards the flat earth theory.

\section{FINDINGS}

The researcher applied close-ended questionnaire and interview to obtain the data. There were two basic questions given on close-ended questionnaire and interview. The first question related to the truth of the flat earth theory and the second question dealt with the action taken to respond the theory. The second question was focused on the students' scientific literacy competence in responding the flat earth theory. Based on PISA 2015 (OECD, 2016), scientific literacy consisted of three, namely: (1) explaining phenomenon scientifically; (2) designing and evaluating scientific investigations; and (3) interpreting data and facts scientifically.

The following Table 5 and 6 describe the result of questionnaire for each question:

Table 5

The Result of Questionnaire for the First Question

\begin{tabular}{lll}
\hline Answer & Total Respondents & $\%$ \\
\hline Accept the theory & 4 & 4.35 \\
Reject the theory & 88 & 95.65 \\
Total & 92 & 100 \\
\hline
\end{tabular}

Table 6

The Result of Questionnaire for the Second Question based on the Competencies

\begin{tabular}{llll}
\hline Answer $(\sqrt{ })$ & Total Respondents & $\%$ & $\Sigma \%$ \\
\hline Square 1 & 58 & 46.77 & \\
Square 2 & 27 & 21.77 & 79.03 \\
Square 3 & 13 & 10.48 & \\
Square 4 & 26 & 20.97 & 20.97 \\
Total & 124 & 100.00 & 100.00 \\
\hline
\end{tabular}


Table 7

Data Distribution based on the Number of Competencies

\begin{tabular}{lll}
\hline Answer $(\sqrt{ })$ & Total Respondents & $\%$ \\
\hline Square 1 & 39 & 59.09 \\
Square 2 & 19 & 28.79 \\
Square 3 & 8 & 12.12 \\
Total & 66 & 100 \\
\hline
\end{tabular}

The results of the interview were reduced to simplify the same data and conclude the data. The interview was done to triangulate the validity of the chosen answers. The questions for interview were the same with the questions for questionnaire added with one more question (Table 8).

Table 8

The Results of Interview Data Reduction

\begin{tabular}{lll}
\hline No. & Question & Reduction data \\
\hline 1. & Do you know the flat earth theory? & $\begin{array}{l}\text { All respondents (100\%) answered "Yes" (They knew about } \\
\text { flat earth theory) }\end{array}$ \\
\hline 2. & Do you accept the flat earth theory? & All respondents rejected \\
\hline 3. & What do you do to investigate the & Data reduction results \\
& Search for information from the internet \\
& Using prior knowledge \\
& Discuss with the teacher and friends \\
& Ask religious experts to get an explanation in a religious \\
& perspective \\
& Looking for research information related to flat earth from \\
& flat earth communities and round earth communities \\
& Read the books about space \\
& Tidak melakukan apapun \\
& Ask to astrologers about it \\
\hline What is on your minds related to the & Girl 1: \\
& The flat earth theory is hoax! The reasons are not supported \\
& with the facts. \\
\hline flat earth theory? & Girl 2: \\
& The flat earth theory is hoax! No reasons at all. \\
\hline & Boy 1: \\
& That's hoax. The important one is I live on this earth. \\
\hline & Boy 2: \\
& The flat earth theory just seeks out the mistakes of round \\
& earth theory and it was made by unknown people.
\end{tabular}

\section{DISCUSSION}

The study was based on the lack of scientific literacy of Indonesian students by PISA and the growing hoax issue that occurred in Indonesia. This study wants to know whether with low literacy, students easily believe with hoax issues mainly related to science issues, namely flat earth theory. Hoax issues can be minimized by equipping students with scientific literacy. Someone with good scientific literacy does not easily believe and make a decision without verification (Abidin et al., 2017). This study investigated student verification steps in responding to flat earth issues. This study uses a questionnaire and interview in the data retrieval process. The close-ended questionnaire contains of two questions and interview contains four questions.

The close-ended questionnaire consists of two questions. The first question on the close-ended questionnaire asked the students' responses towards the flat earth theory. The students' responses were led to accept or reject the truth of the flat earth theory. The result of the first question shows that 88 of 
92 students $(95.65 \%)$ rejected the flat earth theory and the rest of 4 students $(4.35 \%)$ accepted the flat earth theory. The students who accepted the flat earth theory also had answers for the second question of the questionnaire. There was one student who directly accepted the truth of the theory, which was supported by the second question by not doing anything to find any facts about the theory. That shows that students like that only answer baselessly. He did not apply the scientific literacy competencies in responding the flat earth theory. Three other students who believed that this earth is flat applied their scientific literacy in drawing a conclusion that the earth is flat. There was only one student who used his background theories, information and facts (knowledge) as the explanation of the theory. One student had conducted an investigation, literature review and sought out trusted sources as the explanation to make a conclusion. One more student applied the three scientific literacy competences in drawing the conclusion that the earth is flat.

The second question of the questionnaire, the respondents could choose more than one answer depend on the actions they had taken to review the flat earth theory. Based on the Table 6, it is proven that the first option which talked about the competence of explaining the phenomenon scientifically got the highest percentage $(46.77 \%)$. In explaining phenomenon by using this competence, it needs more than an ability to remember and apply the theories, explanatory's ideas, information and facts. The second choice obtained $21.77 \%$. The second competence is designing and evaluating the scientific investigation. Having this competence, the students are going to be able to design and evaluate the scientific investigation process. It includes the ability of collaboration, communication, critical thinking and evaluation. The third option was obtained about $10.48 \%$. Here, the students were able to interpret and analyse data. Besides, they have the ability to argue and criticize. By having this theory, the students could criticize the flat earth theory by doing the investigations. For the fourth option, $20.97 \%$ students did not do anything to find any materials as the explanation to respond the theory. The students who chose this option, even they accepted or rejected the flat earth theory tended to be passive and accepted the concept of the flat earth theory.

Table 6 shows that $79.03 \%$ respondents applied their scientific literacy competence in reviewing the flat earth theory until they could draw a conclusion to accept or reject the theory and $20.97 \%$ did not apply scientific literacy competence in reviewing the theory. The result of individual analysis dealing with the amount of competence mastered by the students in reviewing the flat earth theory shows that:

a. As many as $59.09 \%$ respondents applied first competence of scientific literacy in reviewing. This indicates that students use the ability to remember and apply the knowledge that they already have; identify, produce, and use clear models and representations about flat earth; make and justify jurisdiction appropriately; propose a hypothesis; and explain the potential implications of scientific knowledge for society about flat earth. These results are in line with the results of the interview which mentions that some students only use memories of previous information which states the earth is round. İn addition, students also conduct investigations as a basis for explaining their implications to society through reading books on astronomy and space, and searching for information from the internet.

b. As many as $28.79 \%$ respondents applied second competence of scientific literacy in reviewing. This indicates that students identify how scientists ensure the correctness of research data related to flat earth, research objectives, and generalized explanations. These results are in line with the results of the interview which states that students looking for research information related to flat earth from flat earth communities and round earth communities.

c. As many as $12.12 \%$ respondents applied third competence of scientific literacy in reviewing. This indicates that students discuss arguments to get a connection between theory and appropriate scientific evidence. These results are in line with the results of the interview which states that students hold discussions with teachers and friends, asking experts such as astrologers and religious experts to obtain maximum understanding. 
Based on PISA 2015, a science literate person applies three competences of scientific literacy. The purpose of this study was to describe students' scientific literacy competencies in responding to scientific issues "flat earth theory" and their indications in responding to issues. From the results of data analysis states that most students use scientific literacy competencies in the competition for flat earth issues.

The results of the fourth question state that most students assume that flat earth is an issue of hoaxes in the field of science; there are those who answer the flat earth a conspiracy. Another answer says that flat earth is very possible. From these results, it can be concluded that, most students stated that flat earth theory is only a hoax issue in the field of science.

\section{CONCLUSION AND SUGGESTION}

Based on the findings and discussion, the study was concluded that: the students' responses showed about $95.65 \%$ students rejected the flat earth theory. Furthermore, $79.03 \%$ students applied scientific literacy competence in reviewing the issue of the theory. Almost all students identify the issue of flat earth theory regardless of whether or not students agree with the theory. This percentage shows that students use scientific literacy skills in response to science issues. By using this ability, students can counteract the hoax issues of information or news that are still in doubt.

The teachers are suggested to teach their students with any instructional that improve the students' scientific literacy. They should give a comprehension to their students not to directly support any newest news or information. Contextual instructional development, such as developing teaching media, related to the theory of earth should be developed to minimize the spread of hoaxes dealing with theory about earth. This study can be used as the basis to conduct the further study about the students' achievement on scientific literacy for physics instructional, especially on the solar system discussion.

\section{REFERENCES}

Abidin, Y., Mulyati, T., \& Yunansah, H. (2017). Pembelajaran literasi.. Jakarta: Bumi Aksara.

American Association for Advancement of Science (AAAS). (1993). Benchmarks for science literacy. New York: Oxford University Press.

Brough, C. B. (1872). Proofs that earth is a plane. The Zetetic (Amount Journal of Cosmographical Science), 1(1).

Bybee, R., \& McCrae, B. (2011). Scientific Literacy and Student Attitudes: Perspectives from PISA 2006 science. International Journal of Science Education, 33(1), 7-26. DOI: 10.1080/09500693.2010.518644.

Liu, X. (2009). Beyond science literacy: Science and the public. International Journal of Environmental \& Science Education, 4(3), 301-311.

National Research Council (NRC). (1996). National science education standards. Washington DC: National Academy Press.

National Research Council (NRC). (2007). Taking science to school: Learning and teaching science in Grades K-8. Washington DC: The National Academic Press.

Prahasta, E. (2001). Sistem informasi geografis: Konsep-konsep dasar informatika. Bandung: Informatika.

Rustaman, N. Y. (2007). Kemampuan dasar bekerja ilmiah dalam pendidikan sains dan assesmennya. In Proceeding of The First International on Science Education. Bandung: SPs UPI.

Weinberg, S. (1986). The flat-earth/ round earth controversy. SPAEA, 1-4. 